Focus- for nat i on of repl i cat $i$ on pr ot ei $n A$, act $i$ vat $i$ on of checkpoi nt syst em and DNA repai $r$ synt hesi s i nduced by DNA doubl e-strand br eaks i n Xenopus egg extract

\begin{tabular}{|l|l|}
\hline 著者 & $\begin{array}{l}\text { Kobayashi Takayuki, Tada Shusuke, Tsuyama } \\
\text { Takashi, Mur of ushi H rome, Seki Nasayuki, } \\
\text { Enonnt o Takemi }\end{array}$ \\
\hline $\begin{array}{l}\text { j our nal or } \\
\text { publ i cat i on ti tl e }\end{array}$ & Journal of Cel I Sci ence \\
\hline vol une & 115 \\
\hline number & 15 \\
\hline page r ange & $3159-3169$ \\
\hline year & $2002-08-01$ \\
\hline URL & ht t p: //hdl . handl e. net /2297/14513 \\
\hline
\end{tabular}




\title{
Focus-formation of replication protein A, activation of checkpoint system and DNA repair synthesis induced by DNA double-strand breaks in Xenopus egg extract
}

\author{
Takayuki Kobayashi ${ }^{1}$, Shusuke Tada ${ }^{1, \star}$, Takashi Tsuyama ${ }^{1}$, Hiromu Murofushi ${ }^{2}$, Masayuki Seki ${ }^{1}$ \\ and Takemi Enomoto' \\ ${ }^{1}$ Molecular Cell Biology Laboratory, Graduate School of Pharmaceutical Sciences, Tohoku University, Aoba-ku, Sendai, Miyagi 980-8578, Japan \\ 2Department of Biophysics and Biochemistry, Graduate School of Science, University of Tokyo, Bunkyo-ku, Tokyo 113-0033, Japan \\ *Author for correspondence (e-mail: tada@mail. pharm.tohoku.ac.jp)
}

Accepted 12 May 2002

Journal of Cell Science 115, 3159-3169 (2002) (C) The Company of Biologists Ltd

\section{Summary}

The response to DNA damage was analyzed using a cell-free system consisting of Xenopus egg extract and demembranated sperm nuclei. In the absence of DNAdamaging agents, detergent-resistant accumulation of replication protein $A$ appeared in nuclei after a 30 minute incubation, and a considerable portion of the replication protein A signals disappeared during a further $\mathbf{3 0}$ minute incubation. Similar replication protein A accumulation was observed in the nuclei after a $\mathbf{3 0}$ minute incubation in the extract containing camptothecin, whereas a further 30 minute incubation generated discrete replication protein $\mathrm{A}$ foci. The addition of camptothecin also induced formation of $\gamma-\mathrm{H} 2 \mathrm{AX}$ foci, which have been previously shown to localize at sites of DSBs. Analysis of the time course of DNA replication and results obtained using geminin, an inhibitor of licensing for DNA replication, suggest that the discrete replication protein $A$ foci formed in response to camptothecin-induced DNA damage occur in a DNAreplication-dependent manner. When the nuclei were incubated in the extract containing EcoRI, discrete replication protein $\mathrm{A}$ foci were observed at $\mathbf{3 0}$ minutes as well as at 60 and 90 minutes after incubation, and the focusformation of replication protein A was not sensitive to geminin. DNA replication was almost completely inhibited in the presence of EcoRI and the inhibition was sensitive to caffeine, an inhibitor of ataxia telangiectasia mutated protein (ATM) and ATM- and Rad3-related protein (ATR). However, the focus-formation of replication protein $A$ in the presence of EcoRI was not influenced by caffeine treatment. EcoRI-induced incorporation of biotin-dUTP into chromatin was observed following geminin-mediated inhibition of DNA replication, suggesting that the incorporation was the result of DNA repair. The biotindUTP signal co-localized with replication protein A foci and was not significantly suppressed or stimulated by the addition of caffeine.

Key words: Double-strand DNA break, DNA repair, Checkpoint, Xenopus egg extract, Replication protein A, Camptothecin, EcoRI

\section{Introduction}

DNA double-strand breaks (DSBs) are a serious threat to living cells, and are thought to be caused by ionizing radiation, certain chemotherapeutic drugs and mechanical stress as well as stalled replication forks (Haber, 2000; Karran, 2000; Khanna and Jackson, 2001). Once cells recognize lesions on the DNA, they activate a series of pathways to repair the damage and to arrest the cell cycle in order to gain time for the repair. Although tremendous progress has been made in recent years in elucidating the molecular basis of these processes, there is still a need to clarify the connection between recognition of the DNA lesions, repair and the cellular responses such as checkpoint controls or apoptosis.

Replication protein A (RPA) is the eukaryotic single-stranded DNA binding protein complex, composed of three subunits (Wold, 1997). The complex was originally identified as a factor participating in DNA replication of a cell-free simian virus 40 (SV40) replication system (Fairman and Stillman, 1988; Wobbe et al., 1987; Wold and Kelly, 1988). Observations have since indicated that it functions in many aspects of DNA metabolism such as DNA repair, recombination and transcription as well as DNA replication (Wold, 1997). Functions of RPA in response to DNA damage have also been suggested. Ataxia telangiectasia-mutated protein kinase (ATM) and DNAdependent protein kinase (DNA-PK), which are involved in the primary response to DNA damage (Durocher and Jackson, 2001; Shiloh, 2001), phosphorylate RPA in a DNA-damagedependent manner (Boubnov and Weaver, 1995; Oakley et al., 2001; Shao et al., 1999).

Moreover, RPA has been suggested to associate with the damaged locus on the chromatin. In addition to this association with UV-damaged DNA (Burns et al., 1996; Lao et al., 2000), a number of reports have suggested a link between RPA and DSB repair. Rad51 protein, the eukaryotic homologue of Escherichia coli RecA recombinase, formed foci that increased in number in response to several genotoxic treatments, including ionizing radiation (Haaf et al., 1995). In the cells in which Rad51 foci formed after ionizing radiation, RPA also formed foci, most of which co-localized with the Rad51 foci and sites of DNA repair (Golub et al., 1998; Haaf et al., 1999). 
In addition, localization of BLM and WRN in the nuclear foci containing Rad51 and RPA was also reported (Bischof et al., 2001; Sakamoto et al., 2001). BLM and WRN are eukaryotic DNA helicases homologous to Escherichia coli recombinationassociated DNA helicase, RecQ, and mutations in these genes result in Bloom and Werner syndromes, respectively, which are genetic disorders characterized by genomic instability (Enomoto, 2001; Mohaghegh and Hickson, 2001). These findings suggest that the RPA-Rad51 foci are sites of DNA repair by homologous recombination.

The cell-free system established using extracts derived from Xenopus eggs is useful for biochemical and cytological analysis of the dynamic processes involved in the cell cycle (Blow, 2001; Lohka and Masui, 1983). Because the extract is made from freshly laid eggs that are synchronized at metaphase of meiosis II, upon addition of sperm chromatin, subsequent cell cycle events, such as DNA replication, progress highly synchronously in the extract. Therefore, this system has been widely used in analyses of the mitotic process, the control of chromosomal DNA replication, DNA replication checkpoints, etc. Recently, several attempts have been made using this cellfree system to examine the checkpoint system in response to DNA damage (Costanzo et al., 2000; Guo and Dunphy, 2000; Guo et al., 2000) and the repair of DSBs by nonhomologous end joining (Labhart, 1999). Hence, the cell-free system offers a useful means to analyse the dynamic processes in response to and repair of DSBs.

In studies using the Xenopus cell-free system, focusformation of RPA was implicated in the initiation of DNA replication (Adachi and Laemmli, 1992; Adachi and Laemmli, 1994; Chen et al., 2001). The RPA foci in the nuclei that formed in Xenopus egg extracts were originally identified as components of DNA pre-replication centers (Adachi and Laemmli, 1992; Adachi and Laemmli, 1994). Focus forming activity 1 (FFA-1), a Xenopus homologue of WRN (Yan et al., 1998), was identified as a protein supporting the formation of RPA foci (Yan and Newport, 1995), and an analysis using the dominant-negative form of FFA-1 suggested a function for FFA-1 in DNA replication (Chen et al., 2001). Thus, focusformation of RPA in Xenopus egg extracts has been mainly analyzed in terms of initiation of DNA replication, although its occurrence in response to DNA damage was also reported (Tchang and Mechali, 1999).

The cellular response to DSBs is a complicated linkage of cellular processes, such as recognition of DSBs, activation of checkpoint pathways, selection of an appropriate DNA repair system, repair of lesions and restoration of normal cell cycle events. To understand the molecular basis behind these dynamic cellular responses, we have employed a cell-free system consisting of extract derived from Xenopus eggs. In the present study, we were able to reproduce several important steps in the cellular response to DSBs. As a result, we demonstrated focusformation of RPA in response to DSBs, inhibition of DNA replication by checkpoint pathways, and DNA lesion-induced DNA synthesis that was co-localized with RPA foci.

\section{Materials and Methods}

Preparation of Xenopus egg extract and demembranated sperm

Metaphase arrested cell-free extracts derived from Xenopus eggs were prepared as described (Chong et al., 1997). In brief, freshly laid Xenopus eggs were dejellied in a $2 \%$ cysteine solution, $\mathrm{pH} 7.6$, containing $1 \mathrm{mM}$ EGTA, and rinsed with $15 \mathrm{mM}$ Tris-HCl, $\mathrm{pH}$ 7.6, $110 \mathrm{mM} \mathrm{NaCl}, 2 \mathrm{mM} \mathrm{KCl}, 1 \mathrm{mM} \mathrm{MgSO}{ }_{4}, 2 \mathrm{mM} \mathrm{NaHCO} 3,0.5 \mathrm{mM}$ $\mathrm{Na}_{2} \mathrm{HPO}_{4}$ and $2 \mathrm{mM}$ EGTA, and then with $50 \mathrm{mM}$ Hepes-KOH, $\mathrm{pH}$ 7.6, $50 \mathrm{mM} \mathrm{KCl}, 5 \mathrm{mM} \mathrm{MgCl} 2,2 \mathrm{mM} \beta$-mercaptoethanol and $5 \mathrm{mM}$ EGTA. Then, the eggs were crushed by centrifugation $(10,000 \mathrm{~g}, 10$ minutes). The cytoplasmic fraction was cleared by centrifugation $(84,000 \mathrm{~g}, 20$ minutes) after an addition of cytochalasin B $(10 \mu \mathrm{g} / \mathrm{ml})$. The resultant extract was supplemented with $1 \%$ glycerol and stored in liquid nitrogen.

When required, the extracts were released into interphase by addition of $0.3 \mathrm{mM} \mathrm{CaCl} \mathrm{Cl}_{2}$ and incubated for 15 minutes at $23^{\circ} \mathrm{C}$. The released extract was then supplemented with $250 \mu \mathrm{g} / \mathrm{ml}$ of cycloheximide, 25 $\mathrm{mM}$ phosphocreatin and $15 \mu \mathrm{g} / \mathrm{ml}$ of creatin phosphokinase.

Xenopus sperm nuclei were prepared after demembranation by lysolecithin as described (Chong et al., 1997) and stored at $-80^{\circ} \mathrm{C}$ until use.

\section{Preparation of anti-RPA antiserum}

Xenopus egg extract was diluted with a buffer consisting of $50 \mathrm{mM}$ Hepes-KOH, pH 7.4, $5 \mathrm{mM} \mathrm{MgCl}, 2 \mathrm{mM} \beta$-mercaptoethanol and 0.5 $\mathrm{M} \mathrm{NaCl}$. After an addition of ammonium sulfate $(0.21 \mathrm{~g} / \mathrm{ml})$, precipitates were collected by centrifugation and dissolved in buffer1 (20 mM Tris- $\mathrm{HCl}, \mathrm{pH} 7.5,1 \mathrm{mM}$ EDTA, $0.2 \mathrm{M} \mathrm{NaCl}, 10 \%$ glycerol, $0.2 \mathrm{mM}$ DTT, $0.1 \mathrm{mM}$ phenylmethylsulfonyl fluoride and $0.1 \mathrm{mg} / \mathrm{ml}$ each of pepstatin, leupeptin and chymostatin) followed by dialysis against the same buffer. The dialysate was loaded onto a DEAEcellulose column. After washing the column with buffer-1 containing $0.05 \mathrm{M} \mathrm{NaCl}, \mathrm{RPA}$ was eluted with a linear gradient of $0.05-1 \mathrm{M} \mathrm{NaCl}$ in the same buffer. RPA was eluted at $0.35 \mathrm{M} \mathrm{NaCl}$. The RPA fractions were pooled and loaded onto a single-stranded DNA column. After washing the column with buffer- 1 containing $0.5 \mathrm{M} \mathrm{NaCl}$, RPA was eluted from the column with the same buffer containing $2 \mathrm{M} \mathrm{NaCl}$.

The purified Xenopus RPA was electrophoresed on SDSpolyacrylamide gels. After brief staining of the gels with Coomasie Brilliant Blue, the protein band of the $32 \mathrm{kDa}$ subunit was dissected and homogenized in phosphate-buffered saline (PBS; $137 \mathrm{mM} \mathrm{NaCl}, 2.68$ $\left.\mathrm{mM} \mathrm{KCl}, 8.04 \mathrm{mM} \mathrm{Na} 2 \mathrm{HPO}_{4}, 1.47 \mathrm{mM} \mathrm{KH} \mathrm{PO}_{4}\right)$. Gel homogenate was mixed with complete or incomplete adjuvant and injected into rabbits to prepare antiserum against Xenopus RPA $32 \mathrm{kDa}$ subunit.

\section{Immunofluorescence microscopy}

Preparation of coverslips

Demembranated sperm nuclei (10,000 sperm heads) were incubated in $10 \mu \mathrm{l}$ of Xenopus egg extract at $23^{\circ} \mathrm{C}$ for given periods. During the incubation, 0.05 units/ $\mu$ l of EcoRI (New England BioLabs), $25 \mu \mathrm{M}$ camptothecin (Sigma), $5 \mathrm{mM}$ caffeine (Wako, Osaka, Japan), and 3 $\mu \mathrm{g} / \mathrm{ml}$ of geminin were added to the reaction mixture as indicated. For experiments to detect DNA synthesis, $10 \mu \mathrm{M}$ biotin-16-dUTP (Roche) was also added to the extract prior to the incubation. Then, the nuclei that formed around the sperm chromatin were fixed by addition of 90 $\mu \mathrm{l}$ of ice-cold extraction buffer (EB; $50 \mathrm{mM} \mathrm{KCl}, 50 \mathrm{mM}$ Hepes$\mathrm{KOH}, \mathrm{pH} 7.6,5 \mathrm{mM} \mathrm{MgCl}_{2}$ ) containing 3.7\% formaldehyde and the fixed mixture was diluted with $90 \mu \mathrm{l}$ of ice-cold EB containing $0.5 \%$ Triton X-100. After incubation on ice for 2 minutes, the sample was supplemented with $10 \mu \mathrm{l}$ of $37 \%$ formaldehyde and further incubated for 10 minutes on ice. The mixture was then overlayered onto EB containing $30 \%$ sucrose and fixed on glass coverslips by centrifugation (400 $g$ for 20 minutes).

Observation of RPA and phosphorylated-H2AX ( $\gamma-\mathrm{H} 2 \mathrm{AX})$ accumulation in nuclei

Each coverslip mounted with sample was rinsed three times with 
0.05\% Tween-20 in PBS, and reacted with rabbit anti-Xenopus RPA antisera or antibody against phosphorylated peptide derived from $\gamma$ H2AX (Trevigen Inc) diluted in $0.05 \%$ Tween-20-PBS supplemented with $10 \%$ nonfat milk for 2 hours at room temperature or overnight at $4{ }^{\circ} \mathrm{C}$. Next, the coverslip was rinsed three times with $0.05 \%$ Tween20-PBS and incubated with FITC-labelled donkey anti-rabbit IgG (Jackson Immuno Research Laboratories). It was then rinsed once with $0.05 \%$ Tween 20 -PBS, incubated for 5 minutes in $0.05 \%$ Tween 20-PBS containing $20 \mu \mathrm{g} / \mathrm{ml}$ of propidium iodide (Wako), and rinsed three times with $0.05 \%$ Tween 20-PBS and once with PBS. The coverslip was mounted on a glass slide with PermaFluor Aqueous Mountant (Thermo Shandon, Pittsburgh, PA).

\section{Observation of DNA synthesis}

The preparation used for experiments to detect DNA synthesis with biotin-dUTP was similar to that for the detection of RPA signals with a few changes. After fixation onto a coverslip and incubation with anti-RPA antisera, the coverslip was incubated with Texas Redlabelled anti-rabbit IgG $(\mathrm{H}+\mathrm{L})$ (Vector Laboratories, Burlingame $\mathrm{CA}$ ) and Fluorescein-labelled streptavidin (Vector Laboratories). It was then rinsed twice with $0.05 \%$ Tween-20-PBS and once with PBS. The coverslip was mounted on a glass slide with PermaFluor Aqueous Mountant (Thermo Shandon).

\section{Microscopic observations}

The prepared samples were observed using a Laser Scanning Confocal Imaging System, MRC-1024 (Bio-Rad). A fluorescence microscope (Leica) was also used for experiments to count numbers of discrete RPA foci or focus-positive nuclei. We confirmed that negative controls using non-immune serum generate no or very little signal upon these observations (data not shown).

\section{Isolation of detergent-insoluble nuclear fraction}

Demembranated sperm nuclei (8000 sperm heads) were incubated in $8 \mu \mathrm{l}$ of Xenopus egg extract at $23^{\circ} \mathrm{C}$ for indicated periods. The extract was diluted in $1 \mathrm{ml}$ of nuclear isolation buffer (NIB; $50 \mathrm{mM}$ Hepes$\mathrm{KOH}, \mathrm{pH}$ 7.6, $50 \mathrm{mM} \mathrm{KCl}, 2 \mathrm{mM}$ DTT, $0.5 \mathrm{mM}$ spermidine, $0.15 \mathrm{mM}$ spermine, $1 \mu \mathrm{g} / \mathrm{ml}$ leupeptine and $1 \mu \mathrm{g} / \mathrm{ml}$ pepstatin) supplemented with $0.1 \%$ Triton $\mathrm{X}-100$ and $2.5 \mathrm{mM}$ ATP (TNIBA), and then underlayered with the same buffer containing $15 \%$ sucrose. The nuclei was precipitated at $9000 \mathrm{~g}$ in a swinging bucket centrifuge for 5 minutes at $4^{\circ} \mathrm{C}$. After washing with $1 \mathrm{ml}$ TNIBA, the nuclear precipitate was subjected to $15 \%$ SDS-polyacrylamide gel electrophoresis for immunoblotting or micrococcal nuclease treatment.

\section{Micrococcal nuclease (MNase) treatment of detergent-} insoluble nuclear fraction

Isolated nuclear fraction was suspended in $12 \mu \mathrm{l}$ of TNIBA supplemented with $1 \mathrm{mM} \mathrm{CaCl}_{2}$ and 0.2 units MNase, and incubated for 10 minutes at $37^{\circ} \mathrm{C}$. EGTA ( $1 \mathrm{mM}$ final concentration) was added to terminate the reaction and the mixture was separated into supernatant and precipitated fractions by centrifugation at $1300 \mathrm{~g}$ for 4 minutes at $4^{\circ} \mathrm{C}$. The resultant fractions were subjected to $15 \%$ SDSpolyacrylamide gel electrophoresis for immunoblotting analysis.

\section{Assay for DNA synthesis}

DNA synthesizing activity was measured by the method as described (Chong et al., 1997), with slight modification. In brief, Xenopus egg extract containing $1.85 \mathrm{kBq} / \mu \mathrm{l}$ of $\left[\alpha_{-}{ }^{32} \mathrm{P}\right] \mathrm{dCTP}$ was supplemented with 0.05 units/ $\mu \mathrm{l}$ EcoRI (New England BioLabs), $25 \mu \mathrm{M}$ camptothecin (Sigma), $5 \mathrm{mM}$ caffeine (Wako), and $3 \mu \mathrm{g} / \mathrm{ml}$ of geminin as indicated. The reaction was initiated by the addition of

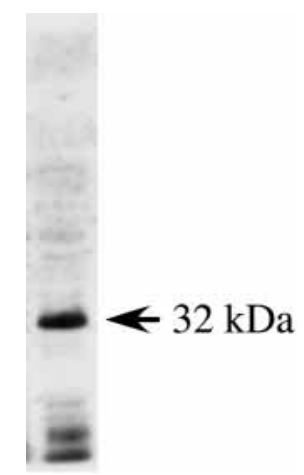

Fig. 1. Characterization of anti-RPA p32 antibody by immunoblotting. $1 \mu \mathrm{l}$ of interphase Xenopus egg extract was subjected to SDS-electrophoresis on a $10 \%$ polyacrylamide gel. The electrophoresed proteins were transferred onto PVDF-membrane and the protein bands that reacted with the antibody were visualized as described in Materials and Methods.

demembranated sperm nuclei (1000 sperm heads/ $\mu 1$ extract). After incubation at $23^{\circ} \mathrm{C}$ for a given period, the reaction was terminated and the mixture was digested by $0.2 \mathrm{mg} / \mathrm{ml}$ proteinase $\mathrm{K}$ in a buffer containing $20 \mathrm{mM}$ Tris- $\mathrm{HCl}, \mathrm{pH}$ 7.5, $5 \mathrm{mM}$ EDTA, and 0.5\% SDS. The digested mixture was then precipitated with cold $10 \%$ TCA, $2 \%$ $\mathrm{Na}_{4} \mathrm{P}_{2} \mathrm{O}_{7}-10 \mathrm{H}_{2} \mathrm{O}$ and filtered through a $25 \mathrm{~mm} \mathrm{GF} / \mathrm{C}$ disc (Whatman). After washing with $5 \%$ TCA, $0.5 \% \quad \mathrm{Na}_{4} \mathrm{P}_{2} \mathrm{O}_{7}-10 \mathrm{H}_{2} \mathrm{O}$ and then with ethanol, the filter was dried and immersed in water. The radioactivity on the filter was measured by detecting emission caused by the Cerenkov effect.

\section{Immunoblotting}

The samples for immunoblotting were electrophoresed on an SDSpolyacrylamide gel and electrically transferred onto Hybond-P PVDF-membrane (Amersham Pharmacia Biotech). The membrane was blocked with PBS containing 3\% bovine serum albumin (BSA) and incubated with anti-RPA p32 antiserum diluted 3000-fold with $0.05 \%$ Tween-20 and 3\% BSA in PBS. After washing with $0.05 \%$ Tween-20-PBS and incubating with horseradish peroxidaseconjugated anti-rabbit $\mathrm{IgG}$, the protein bands that reacted with the anti-RPA antiserum were visualized with ECL western blotting detection reagents (Amersham Pharmacia Biotech).

\section{Preparation of recombinant geminin}

Recombinant geminin was expressed from geminin $\mathrm{H}$ cDNA lacking a destruction box (geminin ${ }^{\mathrm{DEL}}$ ) and affinity-purified as described (McGarry and Kirschner, 1998).

\section{Results \\ Production of antibody against the $32 \mathrm{kDa}$ subunit of Xenopus RPA}

To observe the behavior of RPA in response to DNA-lesions in Xenopus egg extract, we raised an antibody against the middlesized subunit of Xenopus RPA heterotrimer. Xenopus RPA was purified from Xenopus egg extract as desribed in Materials and Methods and the purified fraction was subjected to SDSpolyacrylamide gel electrophoresis. The protein band corresponding to the $32 \mathrm{kDa}$ subunit was excised and rabbits were immunized. The obtained antiserum showed good reaction specificity towards $32 \mathrm{kDa}$ protein in crude Xenopus egg extracts (Fig. 1).

\section{Accumulation of RPA in the nuclei formed in Xenopus egg extract}

To address the accumulation of RPA in the nuclei formed in 
A
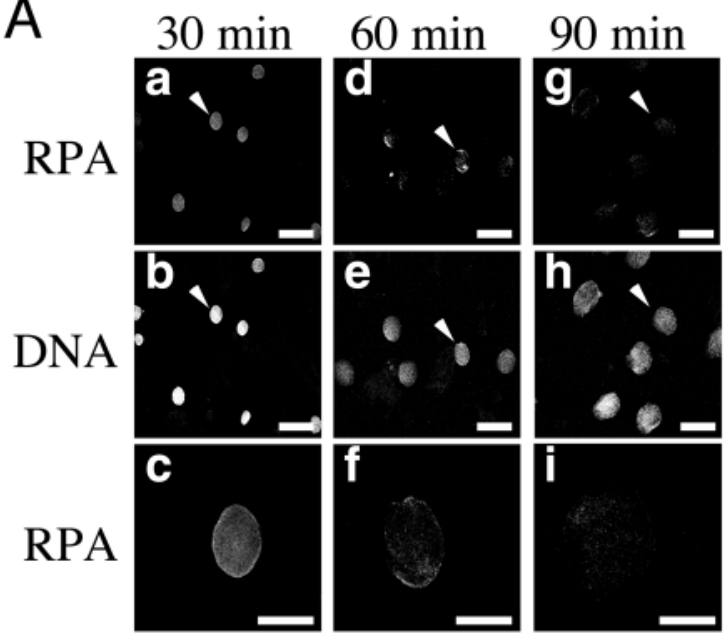

B

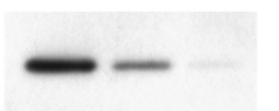

$3060 \quad 90$ (min)

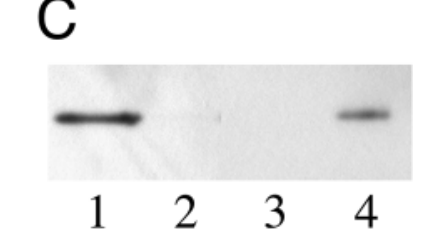

Fig. 2. Focus-formation of RPA in the nuclei incubated with Xenopus egg extract. (A) Demembranated Xenopus sperm nuclei were incubated at $23^{\circ} \mathrm{C}$ for 30 minutes (a-c), 60 minutes (d-f) or 90 minutes (g-i). RPA resistant to detergent treatment is shown in panels $\mathrm{a}, \mathrm{c}, \mathrm{d}, \mathrm{f}, \mathrm{g}$ and $\mathrm{i}$. DNA was visualized using propidium iodide (b,e,h). Panels c, f and $\mathrm{i}$ are enlarged images of the nuclei indicated by arrowheads in panels a, $\mathrm{d}$ and $\mathrm{g}$, respectively. The same nuclei in the 'DNA' panels are also indicated by arrowheads. Bars, $50 \mu \mathrm{m}$ (a,b,d,e,g,h); $20 \mu \mathrm{m}$ (c,f,i). (B) A detergent-insoluble nuclear fraction was prepared from the nuclei incubated in Xenopus egg extract for 30 minutes, 60 minutes or 90 minutes. The p32 subunit of RPA in the nuclear fraction was visualized by immunoblotting after SDSpolyacrylamide gel electrophoresis. (C) The detergent-insoluble nuclear fraction prepared from 30 minute incubated nuclei was incubated for 10 minutes at $37^{\circ} \mathrm{C}$ with (lanes 1,2 ) or without (lanes $3,4)$ MNase, and the reaction mixture was centrifuged. The resultant supernatant (lanes 1,3) and precipitated (lanes 2,4) fractions were subjected to SDS-polyacrylamide gel electrophoresis and immunoblotting.

Xenopus egg extracts, we first examined the behavior of RPA in the absence of DNA-damage-inducing agents by indirect immunofluorescence microscopy (Fig. 2A). The time course of nuclear formation indicated that rounded nuclei appeared around 30 minutes after addition of demembranated Xenopus sperm (data not shown), when DNA replication was about to start in the nuclei (Fig. 3C, closed circle). At this time, the accumulation of RPA occurred in most of the newly formed nuclei (Fig. 2Aa,b). An enlarged image of a representative nucleus indicated that RPA accumulated evenly in the nucleus (Fig. 2Ac). More sensitive observations revealed that the RPA signal appeared to form a large number of minute dots distributed in the whole nucleus (data not shown). However, a considerable portion of the RPA signals disappeared during a further 30 minute incubation (Fig. 2Ad,f), and did not reappear upon further incubation (Fig. 2Ag,i). When geminin, an endogenous inhibitor of the licensing for DNA replication (McGarry and Kirschner, 1998; Tada et al., 2001), was added to the extract, the RPA accumulation observed in the damage non-inducing condition was suppressed almost completely (data not shown).

We then examined chromatin association of RPA under the same conditions by immunoblotting analysis. The $32 \mathrm{kDa}$ band that reacted with the anti-RPA antibody was observed in the detergent-insoluble nuclear fraction isolated after a 30 minute incubation, and the intensity of the band was gradually reduced during further 30 and 60 minute incubations (Fig. 2B). This band was hardly observed in the chromatin fraction isolated before nuclear formation or in the nuclear fraction isolated after incubation in geminin-treated extract (data not shown). To confirm that the detected RPA was associated with chromatin, the nuclear fraction was isolated after a 30 minute incubation, briefly incubated with or without micrococcal nuclease (MNase), and separated into supernatant and precipitated fractions. After MNase treatment, RPA was detected in the supernatant fraction (Fig. 2C), indicating that RPA associates with chromatin.

These results suggest that the minute RPA dots observed here reflect the accumulation of RPA on pre-replication centers reported previously (Adachi and Laemmli, 1992), which form prior to DNA replication and are removed from the sperm chromatin during the progression of DNA replication.

\section{Induction of RPA focus-formation by camptothecin}

Next, we observed the behavior of RPA in the nuclei that formed in the extract containing a DNA damaging agent, camptothecin (CPT). CPT is an inhibitor of DNA topoisomerase I and is known to induce DSBs under certain conditions. The nuclei formed after a 30 minute incubation in the extract containing CPT were smaller than those formed in the absence of CPT (Fig. 3Ab; compare with Fig. 2Ab), possibly reflecting some influence of CPT on the remodeling of chromatin structure during the transition from tightly condensed sperm to nuclei. Although the enlargement of nuclei was slightly delayed in the presence of CPT, it occurred to almost the same degree as in the absence of CPT during a longer incubation (Fig. 3Ae,h).

In spite of the difference in nuclear size, RPA had accumulated in $97 \%$ of nuclei after 30 minute incubation (Fig. $3 \mathrm{Aa})$. Enlarged images of representative nuclei indicated that the accumulation took place evenly in the nucleus (Fig. 3Ac). In contrast to the results obtained in the damage non-inducing condition, RPA-signals were observed in $98 \%$ and $94 \%$ of the nuclei after 60 and 90 minute incubation, respectively (Fig. 3Ad,g). In addition, the CPT-induced RPA signal observed after 60 and 90 minutes formed discrete foci in contrast to the RPA accumulation in the nuclei after 30 minutes (Fig. 3Af,i). Both the number of RPA-positive nuclei and the number of foci in the nucleus after 60 minute incubation were increased being dependent on the concentration of CPT in the extract (data not shown).

To examine whether the CPT-induced discrete RPA-foci were associated with chromatin, we prepared a detergentinsoluble nuclear fraction from nuclei incubated for 60 minutes in CPT-containing extract (Fig. 3B). The amount of RPA in the nuclear fraction was increased by CPT treatment, and RPA was 

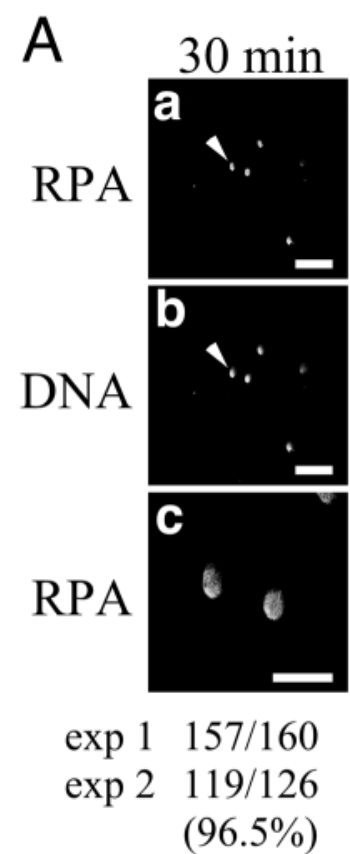

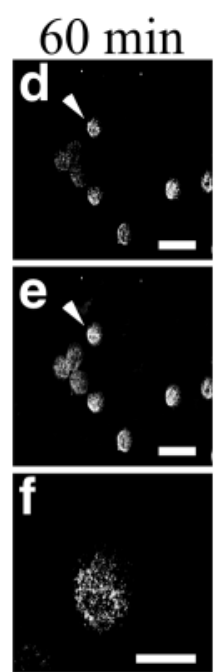

$140 / 143$

$147 / 149$

$(98.3 \%)$

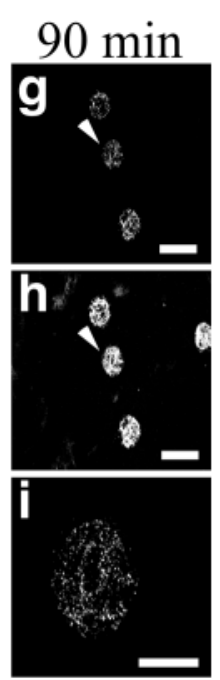

$130 / 142$

$118 / 123$

$(93.6 \%)$
C
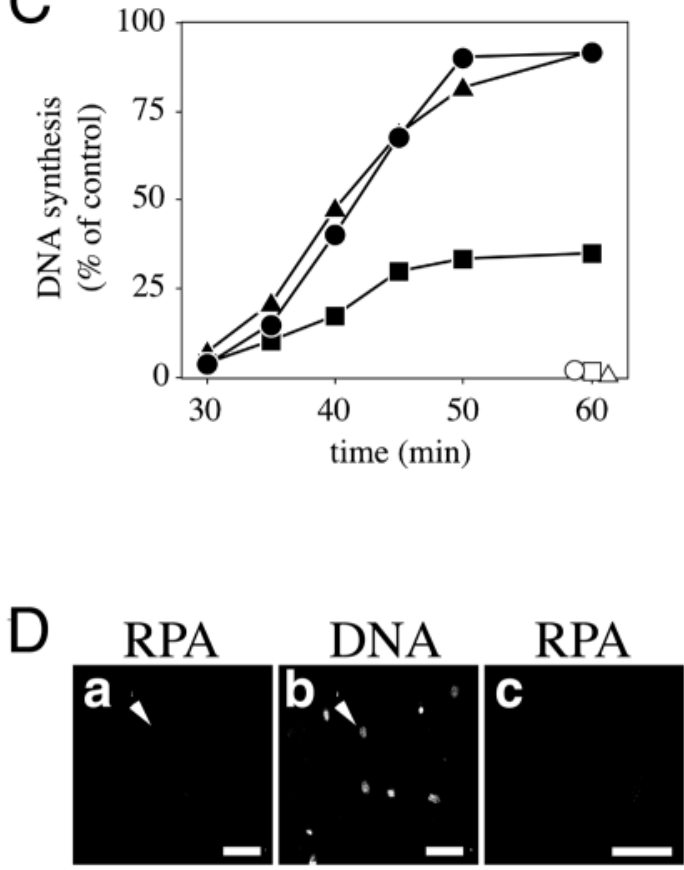

B

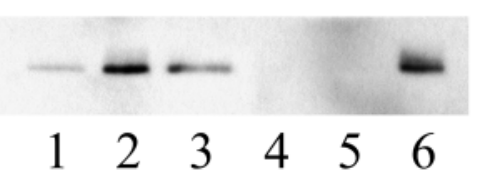

Fig. 3. Focus-formation of RPA and DNA replication in the nuclei incubated with Xenopus egg extract containing CPT. (A) Demembranated Xenopus sperm nuclei were incubated at $23^{\circ} \mathrm{C}$, for the periods indicated, in the presence of CPT. RPA localization (a,c,d,f,g,i) and DNA (b,e,h) were visualized. Panels c, f and i are enlarged images of the nuclei indicated by arrowheads in panels a, $\mathrm{d}$ and g, respectively. The same nuclei in the 'DNA' panels are also indicated by arrowheads. Bars, $50 \mu \mathrm{m}$ (a,b,d,e,g,h); $20 \mu \mathrm{m}$ (c,f,i). Numbers of RPA-accumulated nuclei/observed nuclei from two independent experiments are shown below the panels. The percentages of RPA-accumulated nuclei are also presented in parentheses. (B) A detergent-insoluble nuclear fraction was prepared from the nuclei incubated at $23^{\circ} \mathrm{C}$ for 60 minutes in the absence (lane 1 ) or the presence (lanes 2-6) of $25 \mu \mathrm{M}$ CPT. The nuclear fraction was subjected to SDS-polyacrylamide gel electrophoresis directly (lanes 1,2), or after incubation with (lanes 3,4) or without (lanes 5,6) MNase followed by centrifugal separation of supernatant (lanes 3,5) and precipitated (lanes 4,6) fractions. The p32 subunit of RPA was visualized by immunoblotting. (C) The sperm nuclei were incubated in the extract at $23^{\circ} \mathrm{C}$ for the periods indicated in the presence of $\left[\alpha_{-}{ }^{32} \mathrm{P}\right] \mathrm{dCTP}$. Circles, squares and triangles represent DNA synthesis in the absence, and presence of CPT and CPT+caffeine, respectively. The extent of DNA synthesis is represented as a percentage of accumulative DNA synthesis after a 90 minute incubation under damage-noninducing conditions. 100\% DNA synthesis is estimated to be an amount equivalent to the duplication of about $90 \%$ of input DNA. Open symbols indicate accumulative DNA synthesis during a 60 minute incubation in the presence of geminin. (D) The sperm nuclei were incubated in the extract containing CPT for 60 minutes at $23^{\circ} \mathrm{C}$ in the presence of geminin. Localization of RPA $(\mathrm{a}, \mathrm{c})$ and DNA (b) is shown. Panel $\mathrm{c}$ is an enlarged image of the nucleus indicated by an arrowhead in panel a. The same nucleus in panel $\mathrm{b}$ is also indicated by an arrowhead. Bars, $50 \mu \mathrm{m}(\mathrm{a}, \mathrm{b}) ; 20 \mu \mathrm{m}$ (c).

liberated from the nuclear fraction by brief treatment of MNase, indicating the association of RPA with chromatin.

Fig. 3C shows the time-course of DNA synthesis in the presence and absence of CPT. The level of DNA synthesis was lower in the presence of CPT and reached a plateau after 50 minute incubation, remaining at about $40 \%$ of the level attained in the absence of CPT. DNA synthesis in the presence or absence of CPT was almost completely inhibited by the presence of geminin, indicating that the observed DNA synthesis was due to DNA replication.

CPT is thought to induce DSBs in a DNA replicationdependent manner (Avemann et al., 1988; D’Arpa et al., 1990; Holm et al., 1989; Hsiang et al., 1989; Ryan et al., 1991). Thus, it is likely that the RPA foci that appeared after a 60 minute incubation in the presence of CPT are formed by generation of
DSBs and the formation of RPA foci is prevented by inhibition of DNA replication. This notion is further supported by the fact that geminin inhibited the focus-formation of RPA in the presence of CPT (Fig. 3D).

DSBs reportedly induce rapid phosphorylation of a serine residue within the $\mathrm{C}$-terminus region of histone $\mathrm{H} 2 \mathrm{AX}$, one of three types of H2A histones (Rogakou et al., 1998; Rogakou et al., 1999). This phosphorylation is thought to be a reliable marker for the formation of DSBs because of the specificity of this reaction (Rogakou et al., 1999). To obtain evidence for DSB formation by the presence of CPT in our experimental conditions, we performed indirect immunofluorescence staining by using an antibody that specifically recognizes the phosphorylated form of $\mathrm{H} 2 \mathrm{AX}(\gamma-\mathrm{H} 2 \mathrm{AX})$. Formation of $\gamma$ $\mathrm{H} 2 \mathrm{AX}$ foci was not observed in the absence of DNA damaging 
A

none
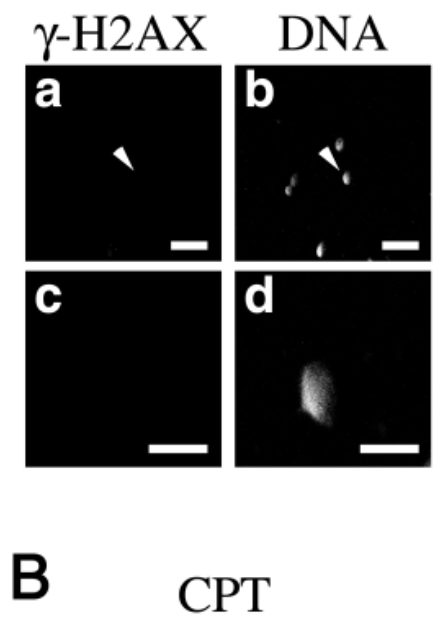

\section{CPT}
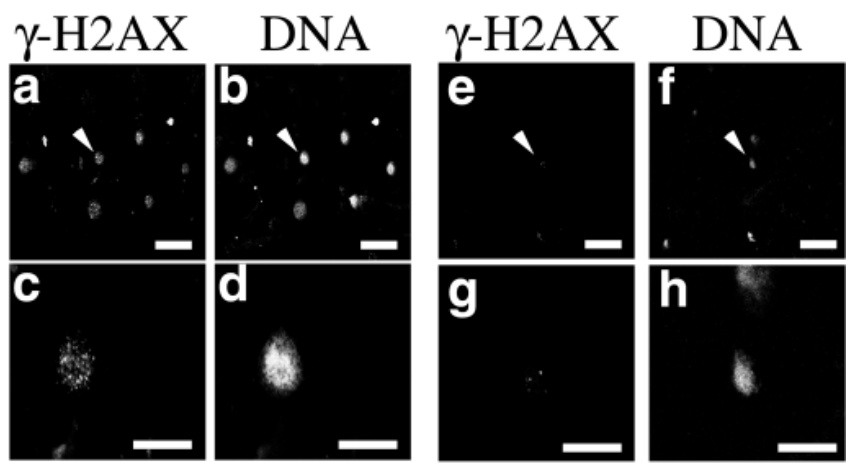

Fig. 4. Formation of $\gamma-\mathrm{H} 2 \mathrm{AX}$ foci in the nuclei incubated in Xenopus egg extract containing CPT. Demembranated sperm nuclei were incubated in Xenopus egg extract with (B) or without (A) CPT. $\gamma$ $\mathrm{H} 2 \mathrm{AX}$ foci formation (a,c,e,g) and DNA (b,d,f,h) in the absence $(a, b, c, d)$ or the presence $(e, f, g, h)$ of geminin were visualized. Panels $c, d, g$ and $h$ are enlarged images of the nuclei indicated by arrowheads in panels a, b, e and f, respectively. Bars, $50 \mu \mathrm{m}$ (a,b,e,f); $20 \mu \mathrm{m}(\mathrm{c}, \mathrm{d}, \mathrm{g}, \mathrm{h})$.

agents (Fig. 4A). By contrast, a large number of $\gamma$-H2AX foci were induced by CPT-treatment and the induction was suppressed almost completely by inhibiting DNA replication with geminin (Fig. 4B).

\section{Induction of RPA focus-formation by EcoRI}

Although our observations and previous reports strongly suggested that CPT caused DSBs in a DNA-replicationdependent manner, we have not succeeded in direct detection of the CPT-induced DSBs in our system. To eliminate the uncertainty of DSB formation by CPT and the complexity caused by the influence of DNA replication, we devised a simple and more direct way to introduce DSBs using restriction enzymes.

Fig. 5A shows the results obtained with the Xenopus egg extract containing 0.05 units/ $\mu$ l of EcoRI, which produces a double-strand DNA cleavage with a four-nucleotide-overhang at the 3 -end of the break. This concentration of EcoRI did not affect the nuclear formation in the Xenopus egg extract (Fig.
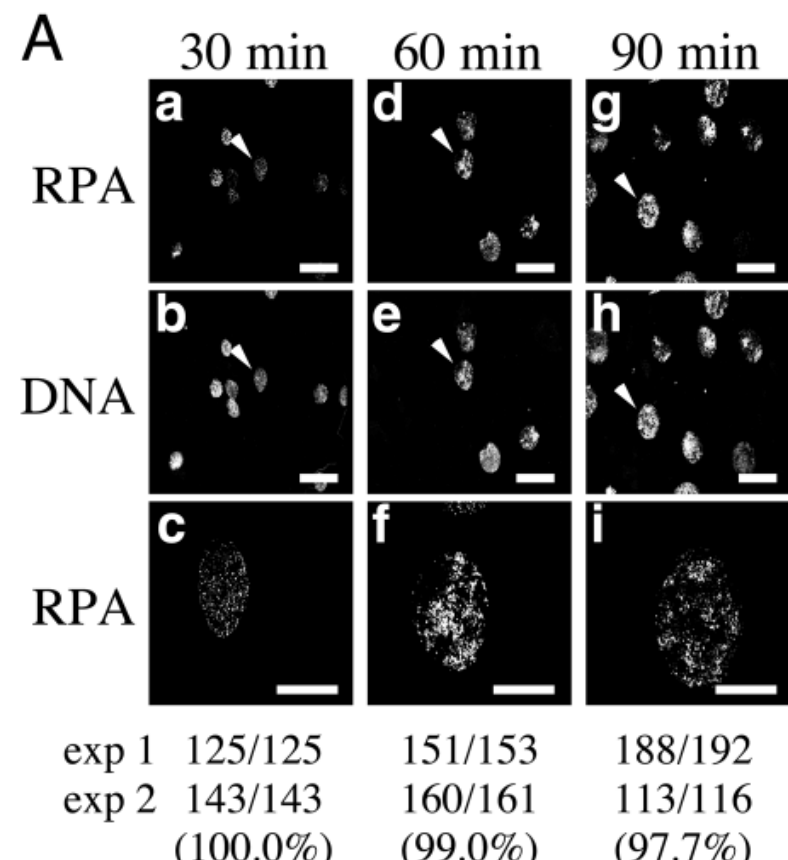

$151 / 153$

$188 / 192$

$160 / 161$

$113 / 116$

$(97.7 \%)$
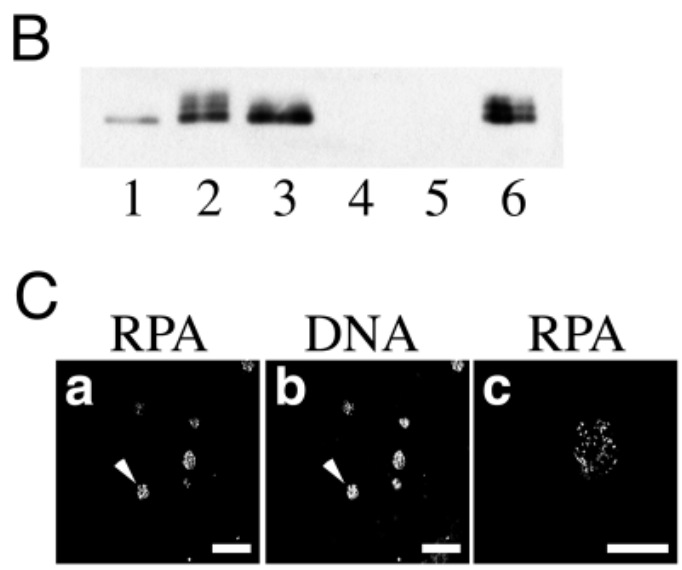

Fig. 5. Focus-formation of RPA in nuclei incubated with Xenopus egg extract containing EcoRI. (A) Demembranated Xenopus sperm nuclei were incubated at $23^{\circ} \mathrm{C}$ for the periods indicated in the presence of EcoRI. Localization of RPA (a,c,d,f,g,i) and DNA (b,e,h) is shown. Panels c, $\mathrm{f}$ and $\mathrm{i}$ are enlarged images of the nuclei indicated by arrowheads in panels a, $\mathrm{d}$ and $\mathrm{g}$, respectively. The same nuclei in the 'DNA' panels are also indicated by arrowheads. Bars, $50 \mu \mathrm{m}$ (a,b,d,e,g,h) or $20 \mu \mathrm{m}$ (c,f,i). Numbers of RPA-accumulated nuclei/observed nuclei from two independent experiments are shown below the panels. The percentages of RPA-accumulated nuclei are also presented in parentheses. (B) A detergent-insoluble nuclear fraction was prepared from the nuclei incubated at $23^{\circ} \mathrm{C}$ for 60 minutes in the absence (lane 1) or the presence (lanes 2-6) of 0.05 units $/ \mu 1$ EcoRI. The nuclear fraction was subjected to SDSpolyacrylamide gel electrophoresis directly (lanes 1,2), or after incubation with (lanes 3,4) or without (lanes 5,6) MNase followed by centrifugal separation of supernatant (lanes 3,5) and precipitated (lanes 4,6) fractions. The p32 subunit of RPA was visualized by immunoblotting. (C) The sperm nuclei were incubated in the extract containing EcoRI for 60 minutes at $23^{\circ} \mathrm{C}$ in the presence of geminin. Localization of RPA (a,c) and DNA (b) is shown. Panel $\mathrm{c}$ is an enlarged image of the nucleus indicated by an arrowhead in panel a. The same nucleus is also indicated by an arrowhead in panel b. Bars, $50 \mu \mathrm{m}(\mathrm{a}, \mathrm{b})$ or $20 \mu \mathrm{m}$ (c). 
5A,b,e,h), which took place about 30 minutes after the addition of the demembranated sperm, and the nuclei gradually enlarged during the incubation. Under these conditions, RPA foci appeared in $100 \%, 99 \%$ and $98 \%$ of the observed nuclei at 30 minutes, 60 minutes and 90 minutes, respectively (Fig. 5A,a,d,g). After the EcoRI-treatment, smeared DNA bands, centered at about $50 \mathrm{kbp}$, were detected by agarose gel electrophoresis, indicating that the restriction enzyme actually digested sperm DNA under these conditions (data not shown). The formation of RPA foci was also observed using EcoRV and PstI, which form blunt and $5^{\prime}$ overhung DNA ends, respectively, or by the addition of EcoRI after nuclear formation (data not shown). Both the number of RPA focipositive nuclei and the number of foci in the nucleus increased in response to the amount of EcoRI (data not shown). Immunoblot analysis indicated that RPA in the detergentinsoluble nuclear fraction was increased by the addition of EcoRI and released from the nuclear fraction by the treatment of MNase (Fig. 5B).

The enlarged images of representative nuclei at 60 minutes and 90 minutes were almost identical to those formed in the presence of CPT (Fig. 5Af,i). By contrast, the RPA signals after a 30 minute incubation in the presence of EcoRI were more similar to those at 60 minutes than after 30 minutes in the presence of CPT (Fig. 5Ac). The difference at 30 minutes may reflect the difference between EcoRI and CPT, which are thought to induce DSBs independently of and dependent on DNA replication, respectively. Indeed, the focus-formation of RPA in the nuclei that formed in the presence of EcoRI was insensitive to the inhibition of DNA replication by the addition of geminin (Fig. 5C).

\section{Suppression of DNA replication induced by DNA damage was released by caffeine}

Next, we assessed DNA replicating activity in the extract containing EcoRI (Fig. 6). While the CPT-treatment allowed nuclei to replicate DNA at approximately $40 \%$ of the level attained in the absence of DNA-damaging agent (Fig. 3C), the EcoRI-treatment prevented DNA replication almost completely. The reduction of DNA replication in the presence of EcoRI or CPT is likely to be due to the activation of a checkpoint system by DSB formation.

To confirm the involvement of a DNA-damage-induced checkpoint system in the reduction of DNA replication, we used caffeine as an inhibitor of ATM and ATR. Although caffeine alone had little or no effect on DNA synthesis in the absence of DNA damaging agents, the ability to synthesize DNA in the presence of EcoRI was restored to control levels by addition of caffeine. This restored DNA synthesis was sensitive to geminin treatment, indicating that DNA replication activity was suppressed by a DNA-damageinduced checkpoint system containing caffeine-sensitive components. Replication of DNA was also restored by caffeine in the nuclei that formed in the presence of CPT (Fig. $3 \mathrm{C}$, closed triangle).

RPA focus-formation induced by DNA damage was not influenced by the caffeine-sensitive checkpoint pathway

Next, we examined whether caffeine also affects the formation

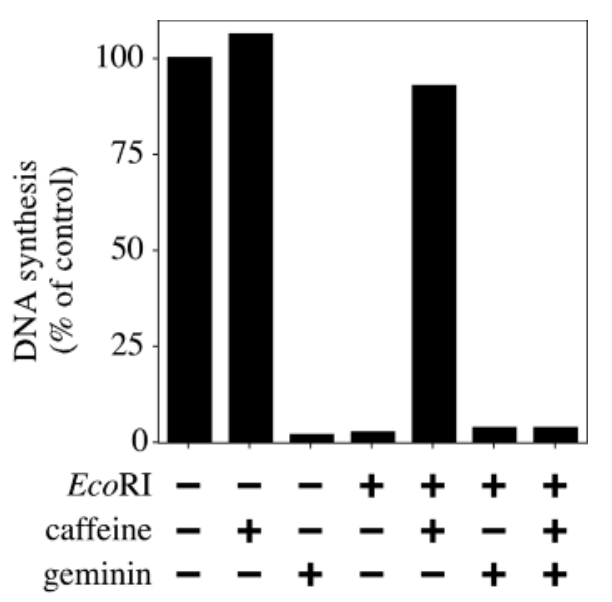

Fig. 6. Suppression of DNA replication by EcoRI-treatment. Demembranated Xenopus sperm nuclei were incubated for 90 minutes at $23^{\circ} \mathrm{C}$ in the extract with or without EcoRI, caffeine and geminin in the presence of $\left[\alpha_{-}{ }^{32} \mathrm{P}\right] \mathrm{dCTP}$. The extent of DNA synthesis is represented as a percentage of accumulative DNA synthesis after a 90 minute incubation in the absence of DNA damaging agents. $100 \%$ DNA synthesis is estimated to be an amount equivalent to the duplication of about $90 \%$ of input DNA.

of RPA foci in the presence of EcoRI. The EcoRI-induced RPA focus-formation proceeded in the presence of caffeine (Fig. 7A). This result indicates that the RPA focus-formation does not occur downstream of the activation of ATM or ATR kinase and the DNA lesion-induced DNA replication arrest. A similar result was obtained with the nuclei formed in the presence of CPT (Fig. 7B).

Detection of DNA repair synthesis that is co-localized with RPA foci and is insensitive to caffeine treatment

We next attempted to detect DSB-induced DNA repair synthesis. Because geminin efficiently inhibited DNA replication, it seemed likely that DNA repair synthesis in geminin-treated nuclei would be easily detected because of the low background of DNA replication. However, as shown in Fig. 3C and Fig. 6, DNA synthesis in the geminin-treated nuclei was hardly detectable by the standard assay. Then, we tried microscopic observation of DNA synthesis after the incorporation of biotin-conjugated dUTP.

Although DNA replication gave quite intense signals of DNA synthesis (data not shown), geminin efficiently suppressed the signal due to DNA replication as expected (Fig. 8a). When EcoRI was added to the extract containing geminin, DNA synthesis was detected in the nuclei (Fig. 8d,g). EcoRIinduced RPA foci in the nuclei were also detected under these conditions, similarly to the previous experiments (Fig. 8e,h), and the location of the loci used to synthesize DNA showed good correlation with that of the RPA foci (Fig. 8f,i). Similar to the focus-formation of RPA, caffeine treatment did not have any apparent effect on DNA repair synthesis observed in this system (Fig. 8j,m) or on the relation of loci of the DNA synthesis and the RPA foci (Fig. 81,o), suggesting that at least part of the DSB repair process is not dependent on ATM or ATR activation. 

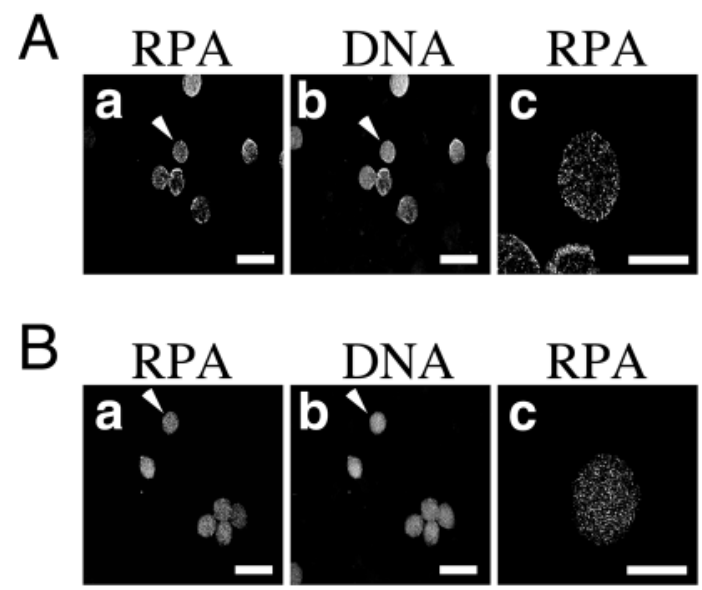

Fig. 7. Caffeine did not affect focus-formation of RPA. Demembranated Xenopus sperm nuclei were incubated in the extract containing $5 \mathrm{mM}$ caffeine for 60 minutes at $23^{\circ} \mathrm{C}$ in the presence of EcoRI (A) or CPT (B). Localization of RPA (a,c) and DNA (b) is shown. Panel $\mathrm{c}$ is an enlarged image of the nucleus indicated by an arrowhead in panel a. The same nucleus is also indicated by an arrowhead in panel b. Bars, $50 \mu \mathrm{m}(\mathrm{a}, \mathrm{b})$ or $20 \mu \mathrm{m}$ (c).

\section{Discussion}

To analyze responses to the formation of DSBs, we developed a cell-free system consisting of extracts derived from Xenopus eggs. We examined the detergent-insensitive localization of RPA in the nuclei that formed in Xenopus egg extract. The antibody used in this study was raised against Xenopus RPAp32, the middle-sized subunit of the RPA-heterotrimer. This antibody recognized a $32 \mathrm{kDa}$ protein in crude Xenopus egg extract and in a chromatin-associated fraction in immunoblot analysis. It also recognized phosphorylated forms of the protein (data not shown).

In the extract containing no DNA damaging agents, RPAaccumulation occurred evenly in the nuclei after a 30 minute incubation, and the accumulation was completely inhibited by geminin-treatment. Geminin is an endogenous protein that selectively binds to and inhibits Cdt1/RLF-B (Tada et al., 2001; Wohlschlegel et al., 2000). Cdt1/RLF-B possesses an activity essential for chromatin loading of MCM/P1 protein complex (Tada et al., 1999; Maiorano et al., 2000; Nishitani et al., 2000), a component of the pre-replicative complex necessary for the initiation of DNA replication (Blow, 2001; Takisawa et al., 2000; Tye, 1999). Therefore, geminin inhibits the initiation of DNA replication and is likely to have no or very little effect on other processes in living cells, including progression of the cell cycle. Thus, geminin is a good tool for eliminating the influence of DNA replication. The sensitivity of the RPA signals to geminin suggests that the accumulation of RPA is dependent on the initiation of DNA replication as described previously (Adachi and Laemmli, 1992; Adachi and Laemmli, 1994; Chen et al., 2001).

The RPA-signal observed by indirect immunofluorescence was significantly reduced at 60 minutes and almost absent at 90 minutes, when DNA synthesis is almost complete (Fig. $3 \mathrm{C}$, closed circle) and most of the MCM proteins were removed from the chromatin (Thömmes et al., 1997) in Xenopus egg extracts. Thus, the disappearance of the RPA- signal during further incubation seems to reflect the removal of RPA from the chromatin during the progression of DNA replication. This notion was supported by the result of immunoblot analysis detecting RPA in the detergentinsoluble nuclear fraction. The sequential alteration in the behavior of RPA seemed to differ between the present study and the study reported previously (Chen et al., 2001). They observed discrete RPA signal even after completion of DNA replication under conditions similar to our damage noninducing conditions. The discrepancy may be caused by the difference in the method used for fixation before immunostaining. A wash of fixed nuclei with $0.1 \%$ Triton $\mathrm{X}$ 100 followed immobilization of nuclei on coverslips by centrifugation in a protocol used by Chen et al., whereas, in our experiments, fixed nuclei were washed with $0.24 \%$ Triton X-100 before immobilization. Another possibility for this discrepancy is the difference in antibodies used for the immunostaining. While Chen et al., used antibodies against the largest subunit or all three subunits of RPA, the antibody we used for this study was specific to the p32 subunit of RPA.

CPT is an inhibitor of DNA topoisomerase I and is known to trap DNA topoisomerase I cleavage complexes resulting in enzyme-linked breaks in the substrate DNA (Hsiang et al., 1985; Hsiang and Liu, 1988; Pommier et al., 1998). The formation of DSBs by CPT is thought to depend on DNA replication on the basis of several lines of evidence (Avemann et al., 1988; D’ Arpa et al., 1990; Holm et al., 1989; Hsiang et al., 1989; Ryan et al., 1991). We analyzed RPA and $\gamma$-H2AX foci formation in the nuclei incubated in CPT-containing Xenopus egg extract and the results further support this notion. Our result also suggested that the nuclear formation was slightly retarded in the extract containing CPT, although the influence was not so effective since no retardation of nuclear enlargement was observed after a 60 minute incubation. Thus, it is possible that CPT disturbed the decondensation of extremely condensed sperm chromatin and the effect of CPT on decondensation induced the formation of the RPA-foci observed in the present study. However, when CPT was added after chromatin decondensation or nuclear formation, it still caused the formation of the RPA foci (data not shown), suggesting that the retardation of the nuclear formation has no or very little effect on the CPT-induced formation of the nuclear RPA foci.

DNA replication in CPT-treated nuclei started after a 30 minute incubation, similar to that observed in the absence of DNA-damage-inducing agents, but ceased at 50 minutes even though the amount of replicated DNA was only about $40 \%$ of that in the control nuclei. This result suggests that DNA lesions arose after the start of DNA replication and activated a DNAdamage checkpoint pathway that inhibited progression of DNA replication. Indeed, the reduction of DNA replicating activity was completely recovered by treatment with caffeine, an inhibitor of ATM and ATR, which play key roles in checkpoint pathways.

Moreover, detailed observations revealed that the RPA accumulation after a 30 minute incubation in CPT-containing extract appeared to be composed of a large number of minute RPA dots evenly distributed in the nuclei (data not shown). The pattern of RPA accumulation was similar to that after a 30 minute incubation in the control extract rather than in EcoRIcontaining extract, suggesting that the presence of CPT in the 


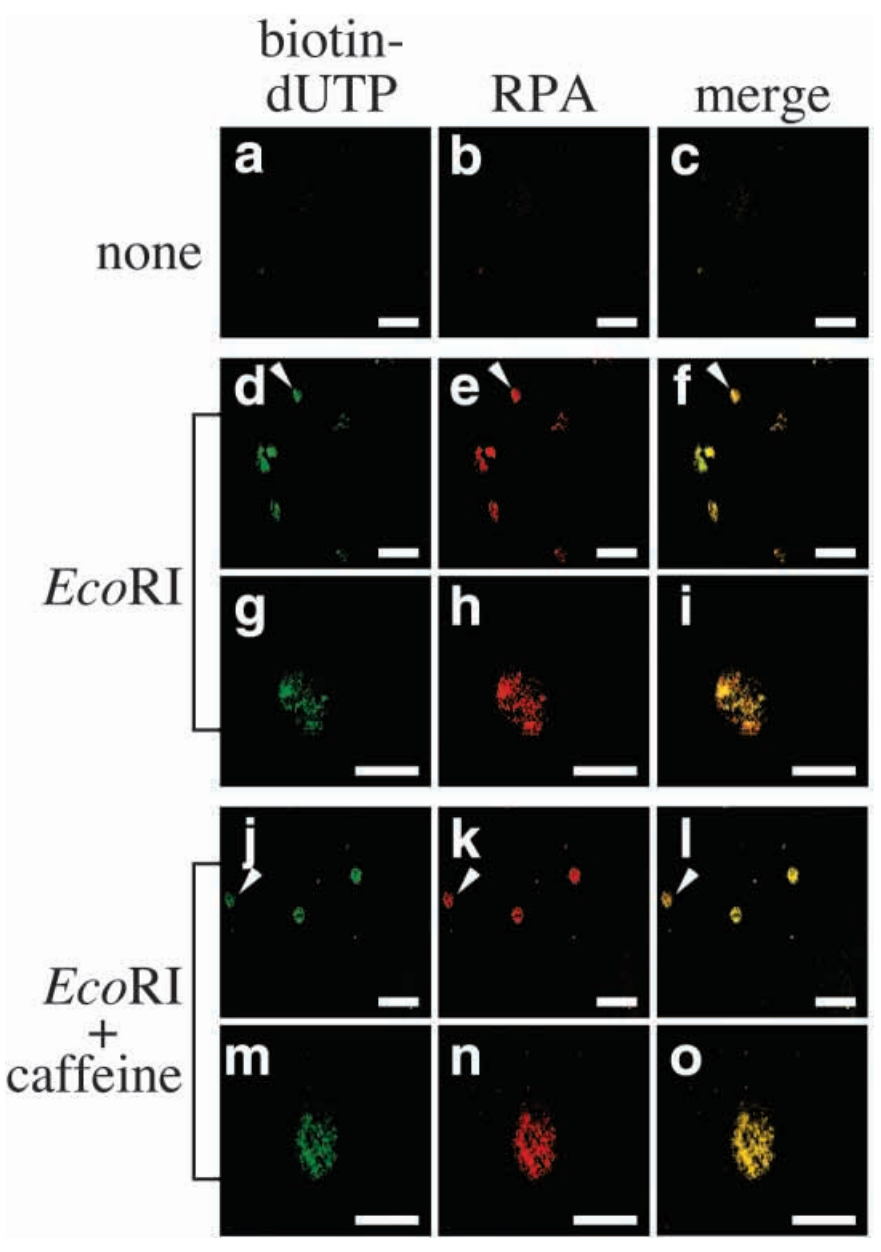

Fig. 8. EcoRI-induced DNA synthesis was co-localized with RPA foci and insensitive to caffeine treatment. Demembranated Xenopus sperm nuclei were incubated in the extract containing geminin and biotin-dUTP for 30 minutes at $23^{\circ} \mathrm{C}$ in the absence (a-c), or presence of EcoRI (d-i) or EcoRI+caffeine (j-o). Localization of biotin-dUTP $(\mathrm{a}, \mathrm{d}, \mathrm{g}, \mathrm{j}, \mathrm{m})$ and RPA $(\mathrm{b}, \mathrm{e}, \mathrm{h}, \mathrm{k}, \mathrm{n})$ is shown in green and red, respectively. Merged images are also shown in panels c, f, i, 1 and o. Panels g, h, i, m, n and o are enlarged images of the nuclei indicated by arrowheads in panels d, e, f, j, k and l, respectively. Bars, $50 \mu \mathrm{m}$ (a-f,j-1); $20 \mu \mathrm{m}$ (g-i,m-o).

extract did not affect the formation of fine RPA dots in the nuclei at 30 minutes, when DNA replication was about to start. In contrast, discrete RPA foci were observed after prolonged incubation, whereas very few discrete RPA foci were observed in the nuclei in the absence of DNA damaging agents. These results suggest that the fine RPA dots at 30 minutes formed at sites where DNA replication was about to start and the discrete foci that appeared after prolonged incubation were located where DNA lesions had been induced during DNA replication by CPT-treatment.

The notion that the RPA foci formed where DNA lesions were induced, was further supported by the experiment using EcoRI in which discrete RPA foci were observed at 30 minutes as well as after prolonged incubation in the absence of DNA replication. Geminin-insensitive, DNA replicationindependent DNA synthesis was induced by EcoRI under these experimental conditions, and was co-localized with EcoRI-
Responses to DSBs in Xenopus egg extract

induced RPA foci. Therefore, the DNA synthesis is likely to be due to the repair of DSBs, further confirming that RPA accumulated at the loci of DNA lesions.

It is possible that the RPA foci observed in the EcoRI-treated or CPT-treated nuclei after a 60 and 90 minute incubation resulted from the failure to extinguish the RPA foci that formed in the nuclei after a 30 minute incubation by inhibiting progression of DNA replication. However, the results obtained in the present study provide evidence against this idea. First, the formation of RPA foci in EcoRI-treated nuclei was insensitive to geminin, which eliminates the formation of fine RPA foci after a 30 minute incubation in the absence of DNA damaging agents. Second, although caffeine-treatment overcame the inhibition of DNA replication by the checkpoint mechanism, it had no effect on the formation of RPA foci in the EcoRI- or CPT-treated nuclei.

The process inhibiting the initiation of DNA replication by a caffeine-sensitive checkpoint system has been discussed in a previous report (Costanzo et al., 2000). The authors showed that the association of $\mathrm{Cdc} 45$ with chromatin was suppressed by ATM, activated by linearized plasmids in Xenopus egg extracts. They also showed that in this ATM-containing fraction, the activity of $\mathrm{Cdk} 2$ and its ability to associate with cyclin E was inhibited. They explained these results by suggesting that Cdc45 loading on chromatin is suppressed by the inhibition of $\mathrm{Cdk} 2 / \mathrm{Cyclin} \mathrm{E}$ protein kinase. The inhibition probably occurs via the activation of ATM, followed by the activation of $\mathrm{Chk} 2 / \mathrm{Cds} 1$ protein kinase, and the suppression of Cdc25A protein phosphatase, which activates $\mathrm{Cdk} 2 /$ Cyclin $\mathrm{E}$ (Costanzo et al., 2000; Falck et al., 2001). All of the above processes should be suppressed after caffeine-treatment via inhibition of the ATM activation.

The result that caffeine did not inhibit the formation of DNA-lesion-induced RPA foci or DNA synthesis suggests that the focus-formation and at least a part of the repair process occurs independently of downstream events of ATM or ATR activation. However, it does not necessarily exclude the involvement of DNA-PK. The concentration of caffeine needed to inhibit DNA-PK activity by $50 \%$ is $10 \mathrm{mM}$ (Sarkaria et al., 1999), higher than levels used in the present study. In addition, DNA-PK has been reported to phosphorylate RPA in response to DNA damage (Niu et al., 1997; Shao et al., 1999; Zernik-Kobak et al., 1997), which suggests that the behavior of RPA is controlled by the phosphorylation catalyzed by DNA-PK.

We have reported here the establishment of a simple cellfree system using Xenopus egg extract, which may permit further study into the recognition and repair of DSBs. Using restriction enzymes and recombinant geminin, the use of which in intact cells is very difficult, we have obtained clear results that indicate accumulation of RPA on chromatin containing DSBs, suppression of DNA replication by DNAdamage-induced checkpoint mechanisms, and co-localization of the DSB-induced DNA synthesis loci and the RPA foci. We have also shown that the recognition of DNA lesions by RPA and DNA synthesis induced by DSB-formation occurs independently of the downstream events of ATM or ATR activation, including the arrest of DNA replication. We think that this system will open the way to detailed analyses regarding the recognition and the repair processes of DSBs. 
We thank Ben Hodgson and Dana Branzei for revision of English in the manuscript. This work was supported by Grants-in-Aid for Scientific Research from the Ministry of Education, Culture, Sports, Science and Technology of Japan, and a Health Sciences Research Grant from the Ministry of Health, Labour and Welfare of Japan.

\section{References}

Adachi, Y. and Laemmli, U. K. (1992). Identification of nuclear prereplication centers poised for DNA synthesis in Xenopus egg extracts: immunolocalization study of replication protein A. J. Cell Biol. 119, 1-15.

Adachi, Y. and Laemmli, U. K. (1994). Study of the cell cycle-dependent assembly of the DNA pre-replication centres in Xenopus egg extracts. EMBO J. 13, 4153-4164.

Avemann, K., Knippers, R., Koller, T. and Sogo, J. M. (1988) Camptothecin, a specific inhibitor of type I DNA topoisomerase, induces DNA breakage at replication forks. Mol. Cell. Biol. 8, 3026-3034.

Bischof, O., Kim, S. H., Irving, J., Beresten, S., Ellis, N. A. and Campisi, J. (2001). Regulation and localization of the Bloom syndrome protein in response to DNA damage. J. Cell Biol. 153, 367-380.

Blow, J. J. (2001). Control of chromosomal DNA replication in the early Xenopus embryo. EMBO J. 20, 3293-3297.

Boubnov, N. V. and Weaver, D. T. (1995). scid cells are deficient in Ku and replication protein A phosphorylation by the DNA-dependent protein kinase. Mol. Cell Biol. 15, 5700-5706.

Burns, J. L., Guzder, S. N., Sung, P., Prakash, S. and Prakash, L. (1996). An affinity of human replication protein A for ultraviolet-damaged DNA. Implications for damage recognition in nucleotide excision repair. J. Biol. Chem. 271, 11607-11610.

Chen, C. Y., Graham, J. and Yan, H. (2001). Evidence for a replication function of FFA-1, the Xenopus orthologue of Werner syndrome protein. $J$. Cell Biol. 152, 985-996.

Chong, J. P., Thommes, P., Rowles, A., Mahbubani, H. M. and Blow, J. J. (1997). Characterization of the Xenopus replication licensing system. Methods Enzymol. 283, 549-564.

Costanzo, V., Robertson, K., Ying, C. Y., Kim, E., Avvedimento, E., Gottesman, M., Grieco, D. and Gautier, J. (2000). Reconstitution of an ATM-dependent checkpoint that inhibits chromosomal DNA replication following DNA damage. Mol. Cell 6, 649-659.

D'Arpa, P., Beardmore, C. and Liu, L. F. (1990). Involvement of nucleic acid synthesis in cell killing mechanisms of topoisomerase poisons. Cancer Res. 50, 6919-6924.

Durocher, D. and Jackson, S. P. (2001). DNA-PK, ATM and ATR as sensors of DNA damage: variations on a theme? Curr. Opin. Cell Biol. 13, 225-231.

Enomoto, T. (2001). Functions of recQ family helicases: possible involvement of Bloom's and Werner's syndrome gene products in guarding genome integrity during DNA replication. J. Biochem. (Tokyo) 129, 501-507.

Fairman, M. P. and Stillman, B. (1988). Cellular factors required for multiple stages of SV40 DNA replication in vitro. EMBO J. 7, 1211-1218.

Falck, J., Mailand, N., Syljuasen, R. G., Bartek, J. and Lukas, J. (2001). The ATM-Chk2-Cdc25A checkpoint pathway guards against radioresistant DNA synthesis. Nature 410, 842-847.

Golub, E. I., Gupta, R. C., Haaf, T., Wold, M. S. and Radding, C. M. (1998). Interaction of human rad51 recombination protein with singlestranded DNA binding protein, RPA. Nucleic Acids Res. 26, 5388-5393.

Guo, Z. and Dunphy, W. G. (2000). Response of Xenopus Cds1 in cell-free extracts to DNA templates with double-stranded ends. Mol. Biol. Cell 11, 1535-1546.

Guo, Z., Kumagai, A., Wang, S. X. and Dunphy, W. G. (2000). Requirement for Atr in phosphorylation of Chk1 and cell cycle regulation in response to DNA replication blocks and UV-damaged DNA in Xenopus egg extracts. Genes Dev. 14, 2745-2756.

Haaf, T., Golub, E. I., Reddy, G., Radding, C. M. and Ward, D. C. (1995). Nuclear foci of mammalian Rad51 recombination protein in somatic cells after DNA damage and its localization in synaptonemal complexes. Proc. Natl. Acad. Sci. USA 92, 2298-2302.

Haaf, T., Raderschall, E., Reddy, G., Ward, D. C., Radding, C. M. and Golub, E. I. (1999). Sequestration of mammalian Rad51-recombination protein into micronuclei. J. Cell Biol. 144, 11-20.

Haber, J. E. (2000). Partners and pathwaysrepairing a double-strand break. Trends Genet. 16, 259-264.

Holm, C., Covey, J. M., Kerrigan, D. and Pommier, Y. (1989). Differential requirement of DNA replication for the cytotoxicity of DNA topoisomerase
I and II inhibitors in Chinese hamster DC3F cells. Cancer Res. 49, 63656368.

Hsiang, Y. H. and Liu, L. F. (1988). Identification of mammalian DNA topoisomerase I as an intracellular target of the anticancer drug camptothecin. Cancer Res. 48, 1722-1726.

Hsiang, Y. H., Hertzberg, R., Hecht, S. and Liu, L. F. (1985). Camptothecin induces protein-linked DNA breaks via mammalian DNA topoisomerase I. J. Biol. Chem. 260, 14873-14878.

Hsiang, Y. H., Lihou, M. G. and Liu, L. F. (1989). Arrest of replication forks by drug-stabilized topoisomerase I-DNA cleavable complexes as a mechanism of cell killing by camptothecin. Cancer Res. 49, 5077-5082.

Karran, P. (2000). DNA double strand break repair in mammalian cells. Curr. Opin. Genet. Dev. 10, 144-150.

Khanna, K. K. and Jackson, S. P. (2001). DNA double-strand breaks: signaling, repair and the cancer connection. Nat. Genet. 27, 247-254.

Labhart, P. (1999). Nonhomologous DNA end joining in cell-free systems. Eur. J. Biochem. 265, 849-861.

Lao, Y., Gomes, X. V., Ren, Y., Taylor, J. S. and Wold, M. S. (2000). Replication protein A interactions with DNA. III. Molecular basis of recognition of damaged DNA. Biochemistry 39, 850-859.

Lohka, M. J. and Masui, Y. (1983). Formation in vitro of sperm pronuclei and mitotic chromosomes induced by amphibian ooplasmic components. Science 220, 719-721.

Maiorano, D., Moreau, J. and Mechali, M. (2000). XCDT1 is required for the assembly of pre-replicative complexes in Xenopus laevis. Nature 404, 622-625.

McGarry, T. J. and Kirschner, M. W. (1998). Geminin, an inhibitor of DNA replication, is degraded during mitosis. Cell 93, 1043-1053.

Mohaghegh, P. and Hickson, I. D. (2001). DNA helicase deficiencies associated with cancer predisposition and premature ageing disorders. Hum. Mol. Genet. 10, 741-746.

Nishitani, H., Lygerou, Z., Nishimoto, T. and Nurse, P. (2000). The Cdt1 protein is required to license DNA for replication in fission yeast. Nature 404, 625-628.

Niu, H., Erdjument-Bromage, H., Pan, Z. Q., Lee, S. H., Tempst, P. and Hurwitz, J. (1997). Mapping of amino acid residues in the p34 subunit of human single-stranded DNA-binding protein phosphorylated by DNAdependent protein kinase and $\mathrm{Cdc} 2$ kinase in vitro. J. Biol. Chem. 272, 12634-12641.

Oakley, G. G., Loberg, L. I., Yao, J., Risinger, M. A., Yunker, R. L., Zernik-Kobak, M., Khanna, K. K., Lavin, M. F., Carty, M. P. and Dixon, K. (2001). UV-induced hyperphosphorylation of replication protein A depends on DNA replication and expression of ATM protein. Mol. Biol. Cell 12, 1199-1213.

Pommier, Y., Pourquier, P., Fan, Y. and Strumberg, D. (1998). Mechanism of action of eukaryotic DNA topoisomerase I and drugs targeted to the enzyme. Biochim. Biophys. Acta 1400, 83-105.

Rogakou, E. P., Pilch, D. R., Orr, A. H., Ivanova, V. S. and Bonner, W. M. (1998). DNA double-stranded breaks induce histone H2AX phosphorylation on serine 139. J. Biol. Chem. 273, 5858-5868.

Rogakou, E. P., Boon, C., Redon, C. and Bonner, W. M. (1999). Megabase chromatin domains involved in DNA double-strand breaks in vivo. J. Cell Biol. 146, 905-916.

Ryan, A. J., Squires, S., Strutt, H. L. and Johnson, R. T. (1991). Camptothecin cytotoxicity in mammalian cells is associated with the induction of persistent double strand breaks in replicating DNA. Nucleic Acids Res. 19, 3295-3300.

Sakamoto, S., Nishikawa, K., Heo, S. J., Goto, M., Furuichi, Y. and Shimamoto, A. (2001). Werner helicase relocates into nuclear foci in response to DNA damaging agents and co-localizes with RPA and Rad51. Genes Cells 6, 421-430.

Sarkaria, J. N., Busby, E. C., Tibbetts, R. S., Roos, P., Taya, Y., Karnitz, L. M. and Abraham, R. T. (1999). Inhibition of ATM and ATR kinase activities by the radiosensitizing agent, caffeine. Cancer Res. 59, 4375-4382.

Shao, R. G., Cao, C. X., Zhang, H., Kohn, K. W., Wold, M. S. and Pommier, Y. (1999). Replication-mediated DNA damage by camptothecin induces phosphorylation of RPA by DNA-dependent protein kinase and dissociates RPA:DNA-PK complexes. EMBO J. 18, 1397-1406.

Shiloh, Y. (2001). ATM and ATR: networking cellular responses to DNA damage. Curr. Opin. Genet. Dev. 11, 71-77.

Tada, S., Chong, J. P. J., Mahbubani, H. M. and Blow, J. J. (1999). The RLF-B component of the replication licensing system is distinct from Cdc6 and functions after Cdc6 binds to chromatin. Curr. Biol. 9, 211-214.

Tada, S., Li, A., Maiorano, D., Mechali, M. and Blow, J. J. (2001). 
Repression of origin assembly in metaphase depends on inhibition of RLFB/Cdt1 by geminin. Nat. Cell Biol. 3, 107-113.

Takisawa, H., Mimura, S. and Kubota, Y. (2000). Eukaryotic DNA replication: from pre-replication complex to initiation complex. Curr. Opin. Cell Biol. 12, 690-696.

Tchang, F. and Mechali, M. (1999). Nuclear import of p53 during Xenopus laevis early development in relation to DNA replication and DNA repair. Exp. Cell Res. 251, 46-56.

Thömmes, P., Kubota, Y., Takisawa, H. and Blow, J. J. (1997). The RLF$\mathrm{M}$ component of the replication licensing system forms complexes containing all six MCM/P1 polypeptides. EMBO J. 16, 3312-3319.

Tye, B. K. (1999). MCM proteins in DNA replication. Annu. Rev. Biochem. 68, 649-686.

Wobbe, C. R., Weissbach, L., Borowiec, J. A., Dean, F. B., Murakami, Y., Bullock, P. and Hurwitz, J. (1987). Replication of simian virus 40 origincontaining DNA in vitro with purified proteins. Proc. Natl. Acad. Sci. USA 84, 1834-1838.
Wohlschlegel, J. A., Dwyer, B. T., Dhar, S. K., Cvetic, C., Walter, J. C. and Dutta, A. (2000). Inhibition of eukaryotic DNA replication by geminin binding to Cdt1. Science 290, 2309-2312.

Wold, M. S. (1997). Replication protein A: a heterotrimeric, single-stranded DNA-binding protein required for eukaryotic DNA metabolism. Annи. Rev Biochem. 66, 61-92.

Wold, M. S. and Kelly, T. (1988). Purification and characterization of replication protein $\mathrm{A}$, a cellular protein required for in vitro replication of simian virus 40 DNA. Proc. Natl. Acad. Sci. USA 85, 2523-2527.

Yan, H. and Newport, J. (1995). FFA-1, a protein that promotes the formation of replication centers within nuclei. Science 269, 1883-1885.

Yan, H., Chen, C. Y., Kobayashi, R. and Newport, J. (1998). Replication focus-forming activity 1 and the Werner syndrome gene product. Nat. Genet. 19, 375-378.

Zernik-Kobak, M., Vasunia, K., Connelly, M., Anderson, C. W. and Dixon, K. (1997). Sites of UV-induced phosphorylation of the p34 subunit of replication protein A from HeLa cells. J. Biol. Chem. 272, 23896-23904. 